\title{
Transplant Age Has Little Effect on Broccoli Head Weight and Diameter
}

\author{
W. J. Lamont ${ }^{1}$ \\ Department of Horticultural Science, North Carolina State University \\ Raleigh, NC 27695
}

Additional index words. Brassica oleracea var. Italica

Premature heading of broccoli renders the crop a complete loss to either a commercial grower or home gardener. Two primary causes of premature heading are exposure to low temperature before head initiation (Fontes et al., 1967) and seedling size at transplanting (Baggett and Mack, 1970). The latter observed that larger broccoli plants (33 to 50 $\mathrm{g} /$ plant) tended to form heads earlier than smaller plants (4 to $13 \mathrm{~g} / \mathrm{plant}$ ) when exposed to the same conditions. I determined whether severe stunting or hardening of broccoli transplants caused by size restriction in container cells and stress induced by the extreme age of the transplants would affect head size and weight.

Broccoli (Brassica oleracea L. var. Italica Plenk.) cultivars evaluated were 'Bravo', 'Premium Crop', and 'Green Valiant'. Three container sizes were used: Todd (Speedling, Sun City, Fla.) planter flats $080 \mathrm{~A}(2.0 \mathrm{~cm}$ wide $\times 4.5 \mathrm{~cm}$ deep, volume $\left.5.9 \mathrm{~cm}^{3}\right)$; Todd $125(3.2 \mathrm{~cm}$ wide $\times 4.6 \mathrm{~cm}$ deep, volume $\left.15.5 \mathrm{~cm}^{3}\right)$; and \#72 plastic cell pak tray liner (CP) (TLC Polyform, Minneapolis) $(3.8 \mathrm{~cm}$ wide $\times 5.0 \mathrm{~cm}$ deep, volume $\left.24.1 \mathrm{~cm}^{3}\right)$. "Old" (217 and 191 days) and "normal" (16 and 43 days) transplants were used in 1985 and 1986, respectively. The transplants were seeded for Fall 1985 planting on 15 Jan. (old) and 4 Aug. (normal) and for Spring

Received for publication 20 May 1991. Accepted for publication $10 \mathrm{Feb}$. 1992. I gratefully acknowledge the support of W.R. Baker, station superintendent, Central Crops Res. Sta., and the technical assistance of D.E. Adams. Steve Weist is gratefully acknowledged for a major contribution in data analysis. The research reported in this publication was funded by the North Carolina Agricultural Research Service. Use of trade names does not imply endorsement by the North Carolina Agricultural Research Service of products named nor criticism of similar products not mentioned. The cost of publishing this paper was defrayed in part by the payment of page charges. Under postal regulations, this paper therefore must be hereby marked advertisement solely to indicate this fact. ${ }^{1}$ Present address: Dept. of Horticulture, Kansas State Univ., Manhattan, KS 66506.
1986 planting on 4 Sept. 1985 (old) and 29 Jan. 1986 (normal). The old and normal transplants were regularly watered and fertilized weekly with a soluble $20 \mathrm{~N}-8.6 \mathrm{P}-16 \mathrm{~K}$ fertilizer injected into the water system. The greenhouse was maintained at 31/18C (maximum/minimum). Before transplanting on 20 Aug. 1985 and 14 Mar. 1986, fresh weights, plant height, stem diameter, and number of nodes were determined on 15 randomly sampled plants per treatment.

Field experiments were conducted at the Central Crops Research Station, Clayton, N.C., on a Norfolk loamy sand (fine-loamy, siliceous, thermic Typic Paledult) with $\mathrm{pH}$ $5.6 \%$ and $0.3 \%$ humic matter. Plots were arranged in a randomized complete-block design with five replications and single-row plots 4.5 -m long on $1.5-\mathrm{m}$ centers, with plants spaced $30.5 \mathrm{~cm}$ apart. In both seasons, fertilizer $\left(94 \mathrm{~N}-47 \mathrm{P}-188 \mathrm{~K}, \mathrm{~kg} \cdot \mathrm{ha}^{-1}\right)$ was broadcast and disked before bed preparation and before application of $0.03-\mathrm{mm}$ black embossed plastic mulch and a drip irrigation tube $(0.20 \mathrm{~mm}$ thick, emission spacing 30 $\mathrm{cm}$, flow rate of 1.5 liters $\mathrm{min}^{-1}$ per $30 \mathrm{~m}$ of row) (Roberts Irrigation Products, San Marcos, Calif.) on 10 Aug. 1985 or mulch alone on 6 Mar. 1986. Irrigation was supplied when soil tensiometers indicated -0.25 $\mathrm{kPa}$. Drip irrigation was used in the fall experiment, whereas overhead irrigation was used in the spring. At harvest, beginning 14 Oct. 1985 and 7 May 1986, heads were cut

Table 1. Broccoli development at the time of transplanting and head production at harvest as influenced by transplant age.

\begin{tabular}{|c|c|c|c|c|c|c|}
\hline \multirow[b]{2}{*}{$\begin{array}{l}\text { Variable age } \\
\text { (days) }\end{array}$} & \multirow[b]{2}{*}{$\begin{array}{l}\text { Fresh wt } \\
(\mathrm{g})\end{array}$} & \multicolumn{2}{|c|}{ Transplants } & \multirow[b]{2}{*}{$\begin{array}{c}\text { Nodes } \\
\text { (no.) }\end{array}$} & \multicolumn{2}{|c|}{ Head production } \\
\hline & & $\begin{array}{l}\text { Plant ht } \\
\text { (cm) }\end{array}$ & $\begin{array}{l}\text { Stem diam } \\
(\mathrm{mm})\end{array}$ & & Head wt & $\begin{array}{l}\text { Head diam } \\
(\mathrm{cm})\end{array}$ \\
\hline & \multicolumn{6}{|c|}{ Fall 1985 harvest } \\
\hline \multirow[t]{2}{*}{$\begin{array}{r}217 \\
16\end{array}$} & $\begin{array}{l}30.3 \mathrm{a}^{\mathrm{z}} \\
28.9 \mathrm{~b}\end{array}$ & $\begin{array}{r}14.2 \mathrm{a} \\
8.1 \mathrm{~b}\end{array}$ & $\begin{array}{l}4.4 \mathrm{a} \\
2.9 \mathrm{~b}\end{array}$ & $\begin{array}{r}15.7 \mathrm{a} \\
3.8 \mathrm{~b}\end{array}$ & $\begin{array}{l}280 \\
270\end{array}$ & $\begin{array}{l}12.9 \\
12.6\end{array}$ \\
\hline & \multicolumn{6}{|c|}{ Spring 1986 harvest } \\
\hline $\begin{array}{r}191 \\
43\end{array}$ & $\begin{array}{l}25.8 \mathrm{a} \\
17.6 \mathrm{~b}\end{array}$ & $\begin{array}{l}14.4 \mathrm{a} \\
12.7 \mathrm{~b}\end{array}$ & $\begin{array}{l}3.5 \mathrm{a} \\
2.8 \mathrm{~b}\end{array}$ & $\begin{array}{r}15.3 \mathrm{a} \\
4.8 \mathrm{~b}\end{array}$ & $\begin{array}{l}300 \mathrm{a} \\
330 \mathrm{~b}\end{array}$ & $\begin{array}{l}12.5 \mathrm{a} \\
12.9 \mathrm{~b}\end{array}$ \\
\hline
\end{tabular}

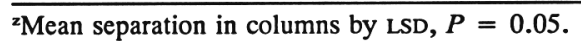
result is consistent with findings of Dufault and Waters (1985). Cultivars performed similarly, with only slight differences in the magnitude of response to age at transplanting. Therefore, cultivars are combined for presentation.

The old transplants resumed active growth after planting and at harvest could not be visually distinguished from plants grown from normal-aged transplants, except for a localized pattern of closely spaced nodes that had developed before transplanting. In conclusion, although there were obvious differences in plant size between old and normal plants at the time of transplanting, there were no consistent treatment effects on head weights or diameters at harvest (Table 1). Therefore, transplant age does not appear to significantly influence the marketable quality of the crop at harvest.

\section{Literature Cited}

Baggett, J.R. and H.J. Mack. 1970. Premature heading of broccoli cultivars as affected by transplant size. J. Amer. Soc. Hort. Sci. 95:403407.

Dufault, R.J. and L. Waters, Jr. 1985. Container size influences broccoli and cauliflower transplant growth but not yield. HortScience 20:682684.

Fontes, M.R., J.L. Ozbun, and S. Sadik. 1967. Influence of temperature on initiation of floral primordia in green sprouting broccoli. Proc. Amer. Soc. Hort. Sci. 91:315-320.

Amer. Soc. Hot. Sci. $91: 315-320$.

with $15 \mathrm{~cm}$-long stalks, and head weights and diameters were measured on 10 plants per treatment per replication.

At the time of planting, the old transplants were woody, with three of four leaves at the growing point and a dense root ball. They were heavier and taller, with a greater stem diameter and more nodes than normal transplants in both years (Table 1). Plants grown in the larger containers (Todd 125 and CP) were also heavier, taller, and had thicker stems and more nodes than those grown in Todd 080A containers (data not presented). This 